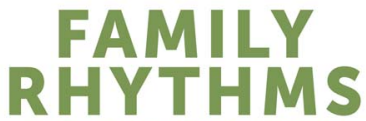

THE CHANGING TEXTURES OF FAMILY LIFE IN IRELAND

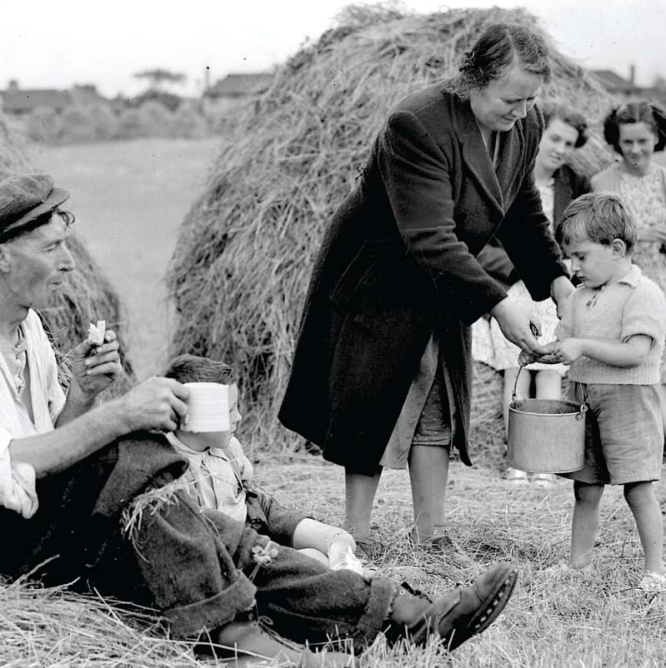

Ruth-Goragh alnd Raviderath 9781526131683 om manch AANEGRAY RUHH GSBAGHTYCPM AND DAVID RALPHe access 


\section{Family rhythms}

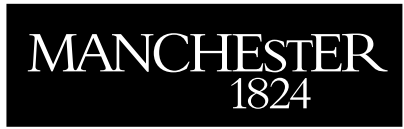

Manchester University Press 
Jane Gray, Ruth Geraghty, and David Ralph - 9781526131683 Downloaded from manchesterhive.com at $04 / 26 / 2023$ 01: 09:46PM via free access 


\title{
Family rhythms
}

\section{The changing textures of family life in Ireland}

\author{
Jane Gray, Ruth Geraghty \\ and David Ralph
}

Manchester University Press 
Copyright $@$ Jane Gray, Ruth Geraghty and David Ralph 2016

The right of Jane Gray, Ruth Geraghty and David Ralph to be identified as the authors of this work has been asserted by them in accordance with the Copyright, Designs and Patents Act 1988.

Published by Manchester University Press

Altrincham Street, Manchester M1 7JA

www.manchesteruniversitypress.co.uk

British Library Cataloguing-in-Publication Data

A catalogue record for this book is available from the British Library

Library of Congress Cataloging-in-Publication Data applied for

ISBN 9780719091513 hardback

ISBN 9780719091520 paperback

First published 2016

The publisher has no responsibility for the persistence or accuracy of URLs for any external or third-party internet websites referred to in this book, and does not guarantee that any content on such websites is, or will remain, accurate or appropriate.

Typeset in 10/12 Photina by

Servis Filmsetting Ltd, Stockport, Cheshire 